IRA-International Journal of Education \&

Multidisciplinary Studies

ISSN 2455-2526; Vol.17, Issue 02 (Q2, 2021)

Pg. no. 94-99.

IRA Academico Research

\title{
A Case Study of Critical Approach Based Ideological and Political Teaching in English Text
}

\section{Pan Cuiqiong}

College of Foreign Studies of Yangtze University, China.

Type of Work: Peer Reviewed.

DOI: 10.21013/jems.v17.n2.p8

DOI URL: https://dx.doi.org/10.21013/jems.v17.n2.p8

\section{How to cite this paper:}

Cuiqiong, P. (2021). A Case Study of Critical Approach Based Ideological and Political Teaching in English Text. IRA-International Journal of Education \& Multidisciplinary Studies (ISSN 2455-2526), 17(2), 94-99. DOl: https://dx.doi.org/10.21013/jems.v17.n2.p8

(C) IRA Academico Research.

(c) EY-NC 4.0 International License subject to a proper citation to the publication source of the work.

Disclaimer: The scholarly papers as reviewed and published by IRA Academico Research are the views and opinions of their respective authors and are not the views or opinions of IRA Academico Research. IRA Academico Research disclaims any harm or loss caused due to the published content to any party.

IRA Academico Research is an institutional publisher member of Publishers International Linking Association Inc. (PILA-CrossRef), USA. IRA Academico Research is an institutional signatory to the Budapest Open Access Initiative. Hungary advocating the open access of scientific and scholarly knowledge. IRA Academico Research is a registered content provider under Open Access Initiative Protocol for Metadata Harvesting (OAl-PMH).

The journal is indexed \& included in WorldCat Discovery Service (USA), CrossRef Metadata Search (USA), WorldCat (USA), OCLC (USA), Open J-Gate (India), EZB (Germany) Scilit (Switzerland), Airiti (China), Bielefeld Academic Search Engine (BASE) of Bielefeld University, Germany, PKP Index of Simon Fraser University, Canada. 


\section{ABSTRACT}

Based on the content of the Critical Approach and category of text in the textbook, this paper attempts to discuss how to use the Critical Approach to explore the writer's intention in the text which also indicates the ideological and political idea in the text. In order to find out the feasible teaching method, this paper chooses the excerpts as the case study. From the detailed analysis of the case, we conclude that the Critical Approach can help us find out the ideological and political ideas in learning text.

Keywords: Critical Approach, ideological and political idea, writer's intention

Nowadays, the ideological and political idea is attached more attention in China education field, especially in-class teaching. So far as English course teaching is concerned, most English teachers have more or less discussed how to teach students ideology, culture or customs involved in the teaching text (马阿婷，2021; 孙小 玲, 2021 ), however, these discussions have only done little touch on the ideological and political idea because they are lack of the theoretical supports. From the previous studies (姚佳力, 2020) about the text, we find that Text Analysis Approach (TAA) in English text teaching is the feasible method for ideological and political teaching. As we know Halliday \& Hasan (1976) defined discourse as any passage, spoken or written, of whatever length, that does form a unified whole. The texts in our textbook occur in the styles like a passage spoken or written, a dialogue and a story. Also, Michael McCarthy (1991) stated that discourse analysis mostly studies the features of language in the text and the relationship between language and ideas in the text. Therefore, to efficiently and feasibly teach the ideological and political idea from teaching text, we can use TAA as the theoretical basis, especially the critical approach in TAA. How to apply a critical approach in English text teaching will be analyzed in the following sections.

\section{Critical Approach in Text Analysis Theory and its Relation to English Course Text}

Text Analysis Theory aims at studying the structure and contents of the text. To analyze these points, the theory includes four approaches including the descriptively structured approach, the social-cultural approach, the cognitive approach and the critical approach. Firstly the descriptively structured approach is a way for analyzing the text structure; then the social-cultural and the cognitive approach are the guidance for contents understandings of the text. Finally, the critical approach aims at probing the authors' intention in the text. Obviously, the first three approaches result in the analysis at a micro-linguistic level which explores the linguistic meaning of the text while the critical approach concerns the depth of the text understanding, indicating the ideological and political interpretation from the text.

In detail, the critical approach in text analysis mainly aims to analyze the depth of meaning reflected in the text, yet different styles of text may have different implied meanings. In English textbooks, generally speaking, the forms of text refer to the passage, the dialogue and the story, which may be written in the styles of narration, explanation, argumentation or conversation. According to different styles, the critical approach based on critical thinking may analyze the depth of the text meaning differently (潘翠琼, 2012). For example, if the text is in narration style, the depth of the text meaning will be focused on the writer or speaker's intention about the merits or demerits of the society; in argumentation style, the depth of the text meaning will be focused on the writer's or speaker's intention about advocating or criticizing something in the society; in explanatory style, the depth of the text meaning will be focused on the writer's or speaker's intention about enriching the readers or listeners' some knowledge; in conversation style, the depth of the text meaning will be focused on the writer's or speaker's intention about the harmonious and full-love relation among people. Therefore, critical approach-based text analysis can be summed 
up in Table 1.

Table 1 Critical Approach -based analysis of the depth of the text meaning

\begin{tabular}{|c|l|}
\hline 4 Discourse Styles & \multicolumn{1}{|c|}{ Critical Approach -based analysis of the depth of the text meaning } \\
\hline Narration style & On the writer's or speaker's intention about the merits or demerits of the society. \\
\hline $\begin{array}{c}\text { Argumentation } \\
\text { style }\end{array}$ & $\begin{array}{l}\text { On the writer's or speaker's intention about advocating or criticizing something spiritual in } \\
\text { the society. }\end{array}$ \\
\hline Explanatory style & $\begin{array}{l}\text { On the writer's or speaker's intention about Enriching the readers or listeners' some } \\
\text { knowledge. }\end{array}$ \\
\hline Conversation style & $\begin{array}{l}\text { On the writer's or speaker's intention about the harmonious and full-love relation among } \\
\text { people. }\end{array}$ \\
\hline
\end{tabular}

From Table 1, we can find that the analysis of the depth of the text meaning is the interpretation and discussion of the ideological and political ideas reflected in the text. Thus, if we want to teach the ideological and political ideas in the teaching text, we just discuss the depth of the text meaning.

\section{Case Study of Critical Approach-based Ideological and Political Teaching in English Text}

2.1 The case itself: This teaching material is the excerpts of Text A Half a Day in Book 1 of Contemporary College English (杨立民, 2013), which can be classified according to the discourse styles in Table 2.

Table 2 Styles Category in Text A

\begin{tabular}{|c|l|}
\hline 4 Discourse Styles & Excerpts of Text A \\
\hline Narration style & $\begin{array}{l}\text { (Para 1). I walked alongside my father, clutching his right hand. All my } \\
\text { clothes were new: the black shoes, the green school uniform, and the red cap. } \\
\text { They did not make me happy, however, as this was the day I was to be thrown } \\
\text { into school for the first time. }\end{array}$ \\
\hline Conversation style & $\begin{array}{l}\text { (Para 3) "Why school?" I asked my father. "What have I done" } \\
\text { (Para.4) "I'm not punishing you”, he said, laughing, "school's not a } \\
\text { punishment. It's a place that makes useful men out of boys. Don't you want to } \\
\text { be useful like your brothers?" }\end{array}$ \\
\hline Explanatory style & $\begin{array}{l}\text { (Para 14) We played all sorts of games. In the music room we sang our first } \\
\text { songs. We also had our first introduction to the language. We saw a globe of } \\
\text { the Earth, which revolved and showed the various continents and countries. }\end{array}$ \\
\hline
\end{tabular}


IRA-International Journal of Education \& Multidisciplinary Studies

\begin{tabular}{|c|l|}
\hline & $\begin{array}{l}\text { We started learning numbers, and we were told the story of the Creator of the } \\
\text { universe. }\end{array}$ \\
\hline Argumentation style & $\begin{array}{l}\text { (Para 15). Our path, however, was hot totally sweet and unclouded. We had to } \\
\text { be observant and patient. It was not all a matter of playing and fooling } \\
\text { around. Rivalries could bring about pain and hatred or give rise to } \\
\text { fighting. .... }\end{array}$ \\
\hline
\end{tabular}

Those are a case study of the text in this paper, yet in real teaching class, the whole text will be analyzed in the same way, i.e. according to the analysis of the whole text, we found that the depth of text meaning is about changing of everything, including school and schooling. How we can correctly get the author's intention in the text lies in the analysis of paragraphs in the text. Thus, in Part 2.2 here, based on the Critical Approach of Text Analysis, the discussion will be carried out.

\subsection{Analysis of the Case from the Perspective of Critical Approach}

1) From Table 1, we know if the text is a kind of narration style, then the understanding of the writer's intention focuses on the merits or demerits of the society. Thus, let's look at the narration style of Para. 1 in Table 2.

The verb clutching shows that "I" does want to depart from my father. The second sentence shows that everything is new. The third sentence shows even though all are new to "me", "I" was not happy, which is abnormal in feeling for people are happy when they have something new, especially for kids. The last sentence tells us the reason why "I" was not happy is because "I" was forced to go to school.

The meaning of Para 1 is about the feelings on the school which is strange to "I". This is a common emotion for children who stay longer with their parents. Thus the writer's intention here is about the enlightenment on a child about the school from family. This is the discussion on the ideological and political ideas, too.

2) From Table 1, we know if the text is a kind of conversation style, then the understanding of the writer's intention focuses on the harmonious and love-full relation between people. Thus look at the conversation style of Para 3 and Para 4 in Table 2.

In para.3, the first question shows that " $I$ " don't understand the reason why " $I$ " must be sent to school. Then the second question is about "my" understanding about schooling, i.e. " $I$ " was sent to school because " $I$ " have done something wrong in father's eyes so that schooling is " $m y$ ” punishment.

In para.4, Father shows his understanding of his son and tells his son that school is the right place for children to become useful men, just like his brothers.

Therefore, the meaning of the two paragraphs is about the explanation to others and persuasion of others on something. The intention of the writer here is about the establishment of good relations between people with different opinions. This is the discussion on the ideological and political ideas, too.

3) From Table 1, we know if the text is a kind of explanatory style, then the understanding of the writer's 
intention focuses on enriching people's knowledge. Thus, let's look at the explanatory style of Para. 14 in Table 2.

The first sentence is the topic sentence, and then in the following 5 sentences, the writer tells detailed information about the sorts of games. Obviously, the games are illustrated very clearly so that we readers can get to know what the games are.

The meaning of Para. 14 is about the orderly activities of the school. The intention of the writer here focuses on the school's role, which implies that school should be a place for people's regularly playing and learning with friendship and love, not the place for punishment. This is the discussion on the ideological and political ideas, too.

4) From Table 1, we know if the text is a kind of argumentation style, then the understanding of the writer's intention focuses on advocating or criticizing something spiritual in the society. Thus, let's look at the explanatory style of Para. 15 in Table 2.

The first sentence refers to the length of life full of different emotions. The second sentence is the attitude to those emotions. The third sentence refers to the experience of a life full of different steps. The last sentence is the competition of life full of pain and hatred even with fighting.

The meaning of this paragraph is about the path of life and the right attitude. The writer's intention here focuses on the appreciation of the length of one's life, which encourages people to experience the world and face the world with the right attitude. Schooling is one part of long life. This is the discussion on the ideological and political ideas, too.

\section{The Implication of the Case Study}

Critical Approach in text analysis can help both teachers and students to find out the ideological and political ideas reflected in the text. But we know this critical approach-based text analysis must be connected with the other three approaches in Text Analysis Theory.

Thus, in our English text teaching, first of all, we need to make students analyze the features of language and the structure of the text, then figure out the cognition of the writer and social significance of the text, finally understand the ideological and political idea in the text based on Critical Approach.

English text teaching has been studied for years, and different researchers more or less offered us some guidance for English class teaching, but those studies did little touch teaching the ideological and political ideas in the text. The paper discussed this aspect from the perspective of the Critical Approach of Text Analysis and it attempts to explore the application of Critical Approach in teaching the depth of text meaning which refers to the ideological and political idea that is advocated in today's education field. We hope the study will offer some guidance for teaching ideological and political ideas in English class and language class.

\section{References}

[1]. Halliday, M.A.K., and Hasan, R. Cohesion in English [M]. London: Longman, 1976.

[2]. Mc Carthy, M. Discourse Analysis for Language Teachers [M]. Cambridge: Cambridge University Press, 1991. 
IRA-International Journal of Education \& Multidisciplinary Studies

[3]. 李佳音. An Empirical Study of College English Reading Teaching from the perspective of Discourse Analysis [D], Shenyan Normal College. 10.27328/d.cnki.gshsc.2020.000741

[4]. 李立民.Contemporary College English.[M]. Beijing: Foreign Language Teaching and Research Press, 2013

[5]. 马阿婷.Ideological and Political Teaching Design in College English and Its Case Study from the perspective of Cultural Man[ J]Journal of Hei Longjiang Teacher Development College. 2021,40(05): 128-140

[6]. 潘翠琼. Critical Thinking, Critical Thinking Teaching and Its Application [M]. Wuhan: Hubei Education Press, 2012

[7]. 姚佳力. On the Application of Discourse Analysis in English Grammar and Writing Teaching. [J] Journal of YAN An Vocational and Technical College. 2020,34(05):52-55

[8]. 孙小玲. The Application of Western-Eastern Cultural Contrast in College English Teaching [J]. Knowledge Corpus. 2021,(11): 3-4 